\title{
Identification of the Microbial Consortium in Sri Lankan Buffalo Milk Curd and Their Growth in the Presence of Prebiotics
}

\author{
NURADHA DEKUMPITIYA, DULANI GAMLAKSHE, SRIYANIE INDRIKA \\ ABEYGUNAWARDENA* and DEHIWALA LIYANAGE JAYARATNE
}

Department of Microbiology, Faculty of Science, University of Kelaniya, Kelaniya, Sri Lanka

\begin{abstract}
The production and consumption of traditionally fermented buffalo milk curd provides many economical and food security benefits to both producers and consumers in the country. To improve this traditional product as a value-added product, an investigation was conducted to elucidate the microbial consortium associated with curd using culture techniques and the microbial load was quantified in the presence of prebiotics. Twenty six samples of curd were analyzed to isolate microorganisms. Two major LAB groups present in the samples were characterized as Lactobacillus and Streptococcus. LABs were further identified as Lactobacillus delbrueckii subsp. lactis, L. plantarum, L. helveticus, Lactobacillus delbrueckii subsp. bulgaricus and L. casei subsp. casei, Streptococcus thermophilus and S. lactis. Saccharomyces cerevisiae, Micrococcus spp., and Bacillus spp. were also present in this microbial consortium. The addition of two types of commercially available prebiotics improved the counts of Lactobacillus in curd samples, despite the difference in the prebiotic compounds.
\end{abstract}

Keywords: Buffalo milk Curd, Lactic Acid Bacteria, Prebiotics

\section{Introduction}

Fermented buffalo milk or 'curd' is a traditional dairy product which has become very popular among Sri Lankans as a dessert and it is served either with treacle or sugar. Due to its popularity, the production of curd has become well established cottage industry in many rural areas in Sri Lanka. The traditional production process has not changed to any great extent and the art of making curd is handed over from one generation to another as in many other countries where traditionally fermented milk is available. Because of its popularity, some large scale dairy producers have also entered into this traditional market. The most popular packaging material in the local market for curd is clay pots sealed with paper cover. Some of the large scale farms and dairy producers use plastic bottles, plastic cups and glass bottles as packaging materials, but the consumer demand is for curd in clay pots (Dharmasena et al., 2013). The producers also believe that curd produced in clay pots have better sensory properties, especially in terms of texture and flavour ((Jayamanne and Adams, 2004). The curd is also produced with cow's milk but the popular product is fermented buffalo milk curd. Curd is also considered as a bio-therapeutic agent. The use of curd as a therapeutic agent in traditional medicine has a long history and this is documented in Ayurveda literature from $600 \mathrm{AD}$ (Nanda et al., 2013).

The identification of microorganisms present in curd collected from different areas of Sri Lanka had shown the invariable presence of streptococci, lactobacilli and yeast in all the samples tested (Abeyagoonasekera, 1981). A field survey and microbiological studies on curd carried out by Dassanayake et al., (1994) reported that $\mathrm{pH}$ ranged from 3.04 to 6.22 whereas maximum recommended is 4.5 They also reported that the Lactic acid bacteria (LAB) such as Lactobacillus fermentum, L. cellobiosus, Streptococcus lactis and Streptococcus lactis sub species diacetylactis were isolated from samples of curd. Considering the importance of consumer market for buffalo milk curd in Sri Lanka, the feasibility of incorporating Bifidobacterium longum NCTC 11818 in buffalo milk curd to produce a probiotic product was investigated by Jayamanna and Adams (2004). The results have indicated that bifidobacteria could be successfully incorporated into buffalo-curd to give a product which has improved acceptability. Generally buffalo milk curd cannot be stored more than two to three days without refrigeration, but consumers prefer freshly prepared curd over the refrigerated product. It has been reported that different bacteria present in commercial dairy products 
decline in their viability during storage of the products and several factors have been identified as responsible for this condition (Medina and Jordano, 1994; Shah, 2000).

The microbiological characteristics of fermented milk produced in different countries are reported in literature; i.e. in India (Shruthy et al., 2011; Mandal and Vuppu, 2013; Nanda et al., 2013), Pakistan (Savadogo et al., 2004), Ghana (Obodai and Dodd, 2006), Indonesia (Yodoamijoyo et al., 1983) and in South Africa (Beukes et al., 2001). According to their studies, the microorganisms present in traditionally fermented milk belong to genera Leuconostoc, Lactobacillus, Streptococcus, Lactococcus and Saccharomyces, etc.

In recent times, there has been a renewal interest in the use of microorganisms as probiotics as well as bio-therapeutic agents and dairy industries are looking forward to expand their market either with new product developments or with improvement of traditional products to value added products. There are three approaches to improve dairy products as value added products. One of the common approaches is the addition of LABs identified as probiotic strains; second method is the addition of prebiotics and the third is the addition of both probiotics and prebiotics to dairy products. Whatever the selected approach, the knowledge of the microbial consortium associated with traditional process is very important and it will evidently enhance the production of value-added curd and its consumption on a larger scale. In this frame of research, one of the approaches considered to address this problem is to incorporate prebiotics to the traditional dairy products to support the growth of LABs in the product. Therefore the present study was undertaken to explore the microbial consortium in the fermented traditional buffalo milk curd and their growth in the presence of prebiotic compounds.

\section{Materials and Methods}

\section{Sample collection and preparation}

Buffalo milk curd samples in clay pots were purchased from three different small scale producers, on the first day of delivery to the retail outlets. Twenty six samples of curd were analyzed to isolate microorganisms. For each experiment, 6 pots of curd were obtained from each product and two were used to prepare a composite sample for microbiological analysis and to measure $\mathrm{pH}$ and acidity and remaining pots were stored at room temperature i.e. $28 \pm 2^{\circ} \mathrm{C}$ for further studies.. The samples were coded as Products-AA, -AB and -AC. The composite curd sample was homogenized with $100 \mathrm{ml}$ of sterile diluents $(0.1 \%$ sterile peptone water $)$, in a stomacher (Stomacher 400 circulator) for 30 s and subjected to serial dilution technique using different media.

\section{Enumeration of microorganisms}

The media used in this study to enumerate LAB, yeast and heterotrophic bacteria were the standard microbiological media. MRS agar (Oxoid), Modified MRS agar (modified by addition of $0.05 \% \mathrm{w} / \mathrm{v}$ cysteine) L-S differential agar (Sigma), Rogosa agar (Oxoid) and M 17 agar (Difco) were used to enumerate the Lactobacillus and Streptococcus species. Each dilution was plated in duplicates and all the plates were incubated in an anaerobic jar flushed with $\mathrm{CO}_{2}$ [gas pack- AnaeroGen (Oxoid)]. The plates containing MRS and L-S differential media were incubated at $32^{\circ} \mathrm{C}$ for $2-4$ days whereas the plates with Rogosa agar medium incubated for 4 days. All the bacterial counts were taken by means of the colony counter (Stuart Scientific colony counter) and the results were expressed in terms of colony forming units (CFU) per gram of product.

For enumeration of yeasts and heterotrophic mesophilic bacteria, dilution plate technique was employed with Malt Yeast Peptone Glucose (MYPG) agar (Difco) and Plate Count Agar (Difco) respectively, and incubated at $32^{\circ} \mathrm{C}$ for $48 \mathrm{hrs}$.

\section{Isolation and characterization of Lactic acid bacteria}

For isolation of LAB, the colonies with different morphological appearance were selected randomly from plates of modified MRS and MRS agar, M17 agar, Rogosa and L-S media. Enrichment method was also employed to isolate the LAB. In enrichment method a known weight ( $3 \mathrm{~g}$ ) of curd sample was added to sterile $25 \mathrm{ml}$ of modified MRS broth and incubated at room temperature for 2-3 days. The enriched culture medium was plated using the agar overlaying technique with modified MRS medium and selective SL medium. The plates were incubated at $32^{\circ} \mathrm{C}$ for 3 days in an anaerobic jar. During the isolation actidion $(10 \mathrm{mg} / \mathrm{l})$ was also added to the modified MRS agar medium in order to suppress the growth of yeasts.

\section{Phenotypic characterization}

The isolates were then subjected to their morphological, biochemical and molecular biological studies. The Gram positive, non-motile and non sporulating, catalase and oxidase negative isolates from MRS and Modified MRS agar, Rogosa agar, M 17 agar and L-S agar were assigned as LAB.

Morphologically varied twelve isolates of Lactobacillus and six isolates of Streptococcus were randomly selected and these isolates were further subjected to the biochemical studies as given in the Harrigan and McCance (1976); Sharpe (1981); Kandler and Weiss (1986); Hammes et al. (1992). The ST medium given by Dave and Shah (1996) were also used to identify the Streptococcus species. Out of these 
isolates, selected organisms were subjected to molecular biological characterization for further identification. Parallel to these experiments, LAB was isolated from 'Branded yogurt samples'. Since branded yogurt is produced by adding two known Lactic acid bacterial cultures i.e. Lactobacillus bulgaricus and Streptococcus thermophilus, and being mixed cultures this was used as quality control measures for media and test methods.

To confirm the identification, two reference cultures Lactobacillus acidophilus (DMBUK 113030) and Streptococcus thermophilus (DMBUK 98050) obtained from the Microbial Culture Collection, Department of
Microbiology, Faculty of Science, University of Kelaniya, were also used as the positive controls.

\section{Molecular Biological Characterization of LAB}

The selected isolates of Lactobacillus species and Streptococcus species were subjected to Molecular biological characterization to confirm the identification of these organisms. For this DNA was extracted from all the selected isolates. The forward and reverse primers used for lactobacilli and streptococci species were specific for L. delbrueckii subsp. bulgaricus and S. thermophilus respectively. These primer sequences are given in Table 1.

Table 1. PCR primers used in this study

\begin{tabular}{llcc}
\hline \multicolumn{1}{c}{ Species } & Sequence (5’ - 3') & Size (bp) & Reference \\
\hline $\begin{array}{l}\text { L. delbrueckii var. } \\
\text { bulgaricus }\end{array}$ & Forward primer 5' CCT CAT CAA CCG GGG CT 3' & 678 & Lick et al., 2001 \\
& $\begin{array}{l}\text { Reverse primer 3' TGA TCC GCT GCT TCA TTT CA 5' } \\
\text { Forward primer 5' CGC CCG GGT GAA GGGT G3' }\end{array}$ & & \\
S. thermophilus & Reverse primer 3' CAC TAT GCT CAG AAT ACA 5' & 968 & Lick et al., 1996 \\
\hline
\end{tabular}

\section{DNA extraction}

The method was adopted from Guo et al. (1999). The bacterial cultures were grown separately on MRS agar at $37^{\circ} \mathrm{C}$ incubation for $24 \mathrm{~h}$. From each plate well separated colonies were obtained with a sterile inoculating loop and suspended in $50 \mu 1$ of PCR buffer microfuge tubes. All the tubes were firmly closed and placed in a water bath at boiling temperature, and boiled for 10 minutes for the cells to break up and the DNA to leak out. After the boiling and allowing the tubes to cool to the room temperature, the tubes were centrifuged at $10,000 \mathrm{rpm}$ for $30 \mathrm{~s}$. The supernatants were collected into fresh tubes and stored in the $-20^{\circ} \mathrm{C}$ freezer to be used as the template DNA for Polymerase Chain Reactions (PCR).

The PCR master mixture was prepared by adding the following chemicals; $10 \times$ PCR buffer $(2.5 \mu \mathrm{l}), 1.5 \mathrm{mM}$ $\mathrm{MgCl}_{2}(1.5 \mu \mathrm{l}), 100 \mu \mathrm{M}$ dNTP $(0.25 \mu \mathrm{l}), 1 \mu \mathrm{M}$ forward primer $(0.25 \mu \mathrm{l}), 1 \mu \mathrm{M}$ reverse primer $(0.25 \mu \mathrm{l}), 1.25 \mathrm{U}$ Taqpolymerase $(0.125 \mu \mathrm{l})$ and Template DNA $(2 \mu \mathrm{l})$. Double distilled water was used to make up the volumes up to 25 $\mu 1$. To appropriately labeled PCR tubes, $2 \mu \mathrm{l}$ each of the DNA samples were added and mixed with $23 \mu \mathrm{l}$ of the PCR master mixture.

The tubes were then placed in the TECHNE Flexigene thermal cycler and the machine was set to carry out the PCR cycles as follows. The initial denaturation was at $94^{\circ} \mathrm{C}$ for 5 min followed by 35 amplification cycles were run for $20 \mathrm{~s}$ at $90^{\circ} \mathrm{C}, 75 \mathrm{~s}$ at $55^{\circ} \mathrm{C}$ and $40 \mathrm{~s}$ at $72^{\circ} \mathrm{C}$ and the final extension at $72^{\circ} \mathrm{C}$ for $3 \mathrm{~min}$.

Each amplified products of $20 \mu \mathrm{l}$ aliquots were separately mixed with $5 \mu 1$ loading dye and subjected to electrophoresis (Bio-rad electrophoresis apparatus) through 1.2\% agarose gel containing ethidium bromide $0.5 \mu \mathrm{g} / \mathrm{ml}$. The amplified DNA products were visualized by exposing the gel to $312 \mathrm{~nm}$ UV rays on the UV Transilluminator (Uvitec 312nm/ STX$35 \mathrm{MS}$ ) and photographed on a Polaroid film with a Polaroid camera (Polaroid-Gelcam).

\section{Characterization of heterotrophic bacteria}

The randomly selected morphologically different heterotrophic bacteria were re-streaked on the nutrient agar and phenotypic characterization was carried out with the resulting colonies. Furthermore these isolates were subjected for their ability to produce acid from different sugars, protease test, modified Hugh and Leifson test as given in Harrigan and McCance (1976).

\section{Characterization of yeasts}

The identification of the isolates was performed following the conventional yeast identification methods. The followed protocol was based on the morphology, sporulation and fermentation of sugars, assimilation of carbon and nitrogen compounds in liquid media, growth at $37^{\circ} \mathrm{C}$ and $40^{\circ} \mathrm{C}$, and 
growth in 50\% glucose and urease (Barnett et al., 1985). The $\mathrm{H}_{2} \mathrm{~S}$ production of the isolates were tested using LA agar (40 g/L glucose, $5 \mathrm{~g} / \mathrm{L}$ yeast extract, $3 \mathrm{~g} / \mathrm{L}$ peptone, 0.2 $\mathrm{g} / \mathrm{L}$ ammonium sulfate, $1 \mathrm{~g} / \mathrm{L}$ lead acetate and $20 \mathrm{~g} / \mathrm{L}$ agar) (Akabanda et al., 2010).

\section{Enumeration of microbial load in curd supplemented with prebiotics}

Hydrolyzed inulin (HI) and Oligofructose (OF), two foodgrade prebiotics, available commercially, were incorporated into curd. The two prebiotic compounds were added separately $(1 \% \mathrm{w} / \mathrm{v})$ to the buffalo milk together with the inoculums during the preparation. Approximately 3-4 g of curd from 1-day old pot was used as the inoculum. The prepared milk pots were allowed to ferment for $8-10 \mathrm{~h}$ at room temperature $\left(29 \pm 2^{\circ} \mathrm{C}\right)$. The viable counts of heterotrophic bacteria, lactic acid bacteria and yeast were determined after $24 \mathrm{~h}$ and $48 \mathrm{hrs}$.

\section{Results and Discussion}

Naturally fermented buffalo milk is a result of fermentation of compounds by a mixture of microorganisms. In this present frame work of research it appeared that it is important to study the total microbial consortium, its' constitutes \& their importance and the physical environment such as $\mathrm{pH}$, acidity, etc. This is because the addition of prebiotics may change the microbial population.

\section{Enumeration of bacteria, titratable acidity and $\mathrm{pH}$ in curd samples}

The lactic acid bacteria were found to be with-in a range of $3.2-3.5 \mathrm{cfu}\left(\log _{10}\right) / \mathrm{g}$ in $24 \mathrm{~h}$ old curd samples on modified MRS medium and it was proliferated to $3.7-7.7 \mathrm{cfu}\left(\log _{10}\right) / \mathrm{g}$ after $48 \mathrm{~h}$ (Table 2). Similar counts were also observed in Rogosa agar and in L-S medium; both media are selective for LAB. The $\mathrm{pH}$ of the curd samples decreased from 5.29 to 4.83 over the three day period and this was corresponded with the increase in acidity as lactic acid. The $\mathrm{pH}$ and acidity of these samples compared favorably with the findings of Dassanayake et al. (1994). The yeast and the heterotrophic bacterial populations were ranged from $4.4-7.7 \mathrm{cfu}$ $\left(\log _{10}\right) / \mathrm{g}$ and $4.3-8.3 \mathrm{cfu}\left(\log _{10}\right) / \mathrm{g}$ after $48 \mathrm{~h}$ respectively (Table 2). In some curd samples both the yeast and LAB counts were low. This may attribute to low cell counts in the starter culture. In the traditional production, a portion of curd taken from previous batch is added as the starter culture and prepared curd was stored in room temperature. The curd cannot store in room temperature more than 2-3 days because after this period it gives sour taste which is not accepted by the consumers.

Table 2. Variation of yeast, heterotrophic bacteria and lactic acid bacteria in Buffalo milk curd samples stored at 29 $\pm 2{ }^{\circ} \mathrm{C}$ for $2-3$ days

\begin{tabular}{|c|c|c|c|c|c|c|}
\hline \multirow{2}{*}{ Curd samples } & \multirow[t]{2}{*}{ Hours } & \multicolumn{5}{|c|}{ Microbial counts [CFU $\left(\log _{10}\right) / g$ of product] } \\
\hline & & $\begin{array}{l}\text { Lactic acid } \\
\text { bacteria } \\
(\text { Medium } 1)^{*}\end{array}$ & $\begin{array}{c}\text { Lactic acid } \\
\text { bacteria } \\
(\text { medium } 2)^{* *}\end{array}$ & $\begin{array}{c}\text { Lactic acid } \\
\text { bacteria } \\
(\text { medium } 3)^{\#}\end{array}$ & Yeast $\S$ & $\begin{array}{c}\text { Heterotrophic } \\
\text { bacteria }^{@}\end{array}$ \\
\hline \multirow[t]{2}{*}{ Product AB } & 24 & $3.19 \pm 0.23^{\mathrm{a}}$ & $4.79 \pm 1.6^{\mathrm{a}}$ & $5.65 \pm 1.54^{\mathrm{a}}$ & $3.19 \pm 0.23^{\mathrm{a}}$ & $3.09 \pm 0.38^{\mathrm{a}}$ \\
\hline & 48 & $6.83 \pm 1.03^{\mathrm{a}}$ & $7.49 \pm 0.31^{\mathrm{a}}$ & $5.24 \pm 0.16^{\mathrm{a}}$ & $6.83 \pm 1.03^{\mathrm{a}}$ & $6.93 \pm 1.05^{\mathrm{a}}$ \\
\hline \multirow[t]{2}{*}{ Product AC } & 24 & $4.30 \pm 0.45^{b}$ & $6.75 \pm 1.34^{\mathrm{b}}$ & $6.16 \pm 0.57^{b}$ & $4.30 \pm 0.45^{\mathrm{b}}$ & $5.67 \pm 1.6^{\mathrm{b}}$ \\
\hline & 48 & $7.73 \pm 0.66^{\mathrm{b}}$ & $9.11 \pm 0.23^{\mathrm{b}}$ & $8.82 \pm 0.17^{\mathrm{b}}$ & $7.73 \pm 0.66^{\mathrm{b}}$ & $8.33 \pm 0.83^{\mathrm{b}}$ \\
\hline \multirow[t]{3}{*}{ Product AA } & 24 & $3.51 \pm 0.54^{\mathrm{c}}$ & NT & NT & $3.92 \pm 0.80^{\mathrm{d}}$ & $4.26 \pm 0.85^{\mathrm{d}}$ \\
\hline & 48 & $3.67 \pm 0.34^{\mathrm{c}}$ & NT & NT & $4.35 \pm 0.80^{\mathrm{d}}$ & $4.31 \pm 0.84^{\mathrm{d}}$ \\
\hline & 72 & $3.60 \pm 0.40^{c}$ & NT & NT & $4.88 \pm 0.77^{\mathrm{d}}$ & $4.45 \pm 0.86^{\mathrm{d}}$ \\
\hline
\end{tabular}

( $\mathrm{SD}=$ standard deviation; NT - Not tested; CFU = colony forming units)

Medium 1* - Modified MRS agar; Medium 2** $\quad$ - L-S differential medium

Medium 3\# - Rogosa medium; Yeast ${ }^{\S}$ - MYPG agar;

Heterotrophic bacteria ${ }^{@}$ - Plate Count agar

${ }^{\text {a }}$ Each value is the mean \pm SD of eight observations in four separate experiments

${ }^{b}$ Each value is the mean \pm SD of eight observations in four separate experiments

c each value is the mean \pm SD of ten observations in ten separate experiments

${ }^{\mathrm{d}}$ each value is the mean $\pm \mathrm{SD}$ of eight observations in eight separate experiments 


\section{Phenotypic characterization of lactic acid bacteria}

Total of 96 isolates obtained from culturing curd in MRS agar, modified MRS agar, L-S agar, M 17 agar and Rogosa agar. Based on their cell morphological characters and their negativity for catalase and oxidase tests, they were identified as LAB. Out of the 96 isolates, 66 (69\%) were identified as Lactobacillus spp. and 20 (21\%) as Streptococcus spp. The seven isolates (7\%) obtained from M 17 medium and three $(3 \%)$ isolates obtained from Rogosa agar, had oval shaped cells. These may be Lactococcus species but the identification was not confirmed.

Lactobacillus acidophilus $\left(\mathrm{L}_{1}\right)$ was used as the reference culture as well as a positive control in the identification programme. Morphologically different twelve isolates of Lactobacillus obtained from curd were subjected to biochemical characterization. Results based on fermentation pattern revealed that many of the selected isolates from curd have the ability to ferment glucose and lactose, but fermentation of other sugars may be species or strain dependent (Table 3). After considering the fermentation pattern of carbohydrates and the results of the biochemical tests given by Harrigan and McCance (1976), Kandler and Weiss (1986), Hammes et al. (1992), the ten lactobacilli isolates were determined as representative of the obligate homofermentative species i.e. Lactobacillus delbrueckii. Depending on the sugar fermentation pattern and other biochemical characters these isolates were identified as L. delbrueckii subsp. lactis and L. delbrueckii subsp. bulgaricus (Table 3 ).

Based on the results of taxonomic studies, some Lactobacillus isolates were determined as L. helveticus and $L$. plantarum because their morphological, cultural and biochemical characteristics were in agreement with those species described by Kandler and Weiss (1986). Colonies of unknown isolates on M17 agar and Rogosa agar appeared as pinpoint colonies that were indistinguishable from the colonies of the reference strain of $S$. thermophilus (DBUMK 98050). These isolates were able to clot milk following 18 $\mathrm{h}$ incubation at $45{ }^{\circ} \mathrm{C}$ and they showed very much similar morphological and biochemical characters to that of the reference culture. Therefore these isolates were identified as S. thermophilus (Table 4). There were some streptococcal isolates that did not produce yellow colonies on ST medium. The biochemical characters of these isolates were closest to Streptococcus lactis (Table 4).

The seven isolates selected from M17 agar medium were gram positive non motile and oval shaped and able to hydrolyze arginine. They were able to produce acid from lactose, glucose, sucrose and arabinose but did not produce acid from raffinose and $\mathrm{CO}_{2}$ from citrate. They were very much similar to Lactococcus species but further identification is required before confirm the results.

\section{Molecular identification of isolated lactic acid bacteria}

The results of the PCR studies revealed that bands given by all the tested isolates were more or less in a similar range (Figure 1). Hence this confirmed that all the isolates were indeed Lactobacillus isolates. Lactobacillus species obtained from curd gave gel bands, the sizes of which were in the 900 bp region. The expected size of the amplified region was 687 base pairs (bp) for L. delbrueckii subsp. bulgaricus (Lick et al., 2001). The isolate showed gel bands which corresponded to approximately $680 \mathrm{bp}$ was also identified phenotypically as L. delbrueckii subsp. bulgaricus due to its very narrow sugar profiles.

The reference culture i.e. Lactobacillus acidophilus gave a gel band, the size of which was $750 \mathrm{bp}$ and this did not correspond to any of the isolated species (Figure 1). Five Lactobacillus isolates gave similar gel pattern and by considering the carbohydrate fermentation patterns and other biochemical characters, they were identified as $L$. delbrueckii subsp. lactis and two Lactobacillus species were identified as L. delbrueckii (Table 3).

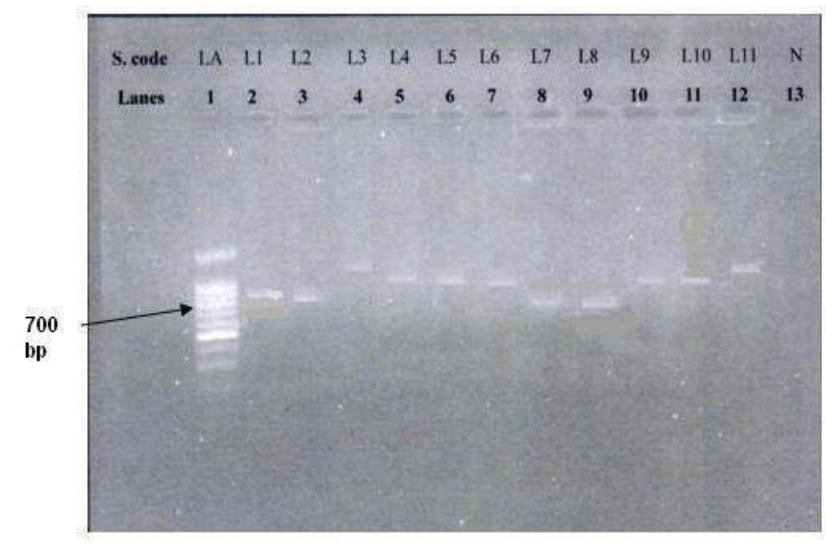

Figure 1. Agarose gel electrophoresis of the PCR amplified DNA for bacterial genomic DNA extracted from 11 bacterial isolates. Lane 1- 100bp ladder (marker), Lane 2- $L$. acidophilus DMBUK 113030 (positive control) $\left(\mathrm{L}_{1}\right)$, Lane 3- $L$. delbrueckii $\left(\mathrm{L}_{2}\right)$, Lane 4 - 8 isolated Lactobacillus species Lane 9- Lactobacillus delbrueckii subsp. bulgaricus $\left(\mathrm{L}_{8}\right)$, Lane 10 -12- isolated Lactobacillus species, Lane 13- Negative control 
Dekumpitiya et al., : J. Food Sci. Technol. Nepal, Vol. 9 (20-30), 2016

Table 3. Physiological and Biochemical characteristics of lactobacilli species isolated from buffalo milk curd and their identification

\begin{tabular}{|c|c|c|c|c|c|c|c|c|c|c|c|c|c|c|c|c|c|c|c|c|c|c|c|c|}
\hline $\begin{array}{l}\text { Code } \\
\text { no. }\end{array}$ & Sample & 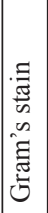 & 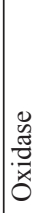 & 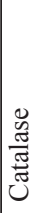 & 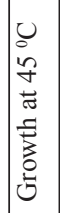 & 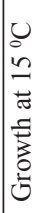 & 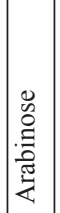 & 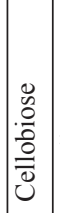 & 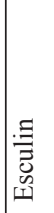 & 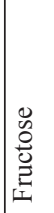 & 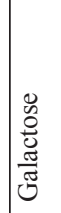 & 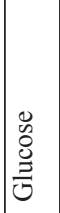 & 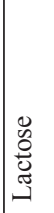 & 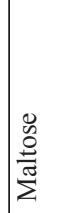 & 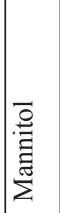 & 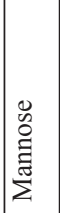 & 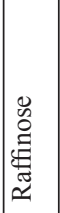 & $\begin{array}{l}\ddot{0} \\
0 \\
0 \\
\vec{\approx} \\
\vec{\approx}\end{array}$ & 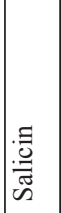 & 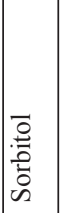 & 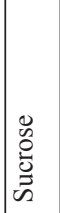 & 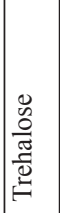 & 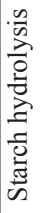 & Lactobacillus sp. \\
\hline $\mathrm{L}_{1}$ & $\mathrm{RC}$ & + & - & - & + & - & - & + & + & + & + & + & + & + & - & + & + & - & + & - & + & + & + & Lactobacillus acidophilus \\
\hline $\mathrm{L}_{2}$ & Yoghurt & + & - & - & + & - & - & - & - & + & - & + & + & + & - & + & + & - & - & - & - & - & - & L. delbrueckii \\
\hline $\mathrm{L}_{3}$ & Curd & + & - & - & & - & - & - & - & + & - & + & - & - & - & - & - & - & - & - & + & - & - & Lactobacillus sp. \\
\hline $\mathrm{L}_{4}$ & Curd & + & - & - & + & - & - & + & + & + & + & + & + & - & - & + & + & - & + & - & + & - & - & $\begin{array}{l}\text { L. delbrueckii subsp. } \\
\text { lactis. }\end{array}$ \\
\hline $\mathrm{L}_{5}$ & Curd & + & - & - & + & - & - & - & - & + & - & + & + & - & - & + & + & - & + & - & + & + & - & $\begin{array}{l}\text { L. delbrueckii subsp. } \\
\text { lactis. }\end{array}$ \\
\hline $\mathrm{L}_{6}$ & Curd & + & - & - & + & - & - & - & - & + & - & + & + & - & - & + & + & - & + & - & + & + & - & $\begin{array}{l}\text { L. delbrueckii subsp. } \\
\text { lactis. }\end{array}$ \\
\hline $\mathrm{L}_{7}$ & Curd & + & - & - & + & - & - & - & - & + & - & + & + & + & - & + & - & - & - & - & - & + & - & L. delbrueckii \\
\hline $\mathrm{L}_{8}$ & Yoghurt & + & - & - & + & - & - & - & - & - & - & + & + & - & - & - & - & - & - & - & - & - & - & $\begin{array}{l}\text { L. delbrueckii subsp. } \\
\text { bulgaricus }\end{array}$ \\
\hline $\mathrm{L}_{9}$ & Curd & + & - & - & + & - & - & - & - & + & - & + & + & - & - & + & - & + & + & - & 1 & + & - & L. delbrueckii subsp. lactis \\
\hline $\mathrm{L}_{10}$ & Curd & + & - & - & + & - & - & - & - & + & - & + & + & - & - & + & - & + & + & - & + & + & - & $\begin{array}{l}\text { L. delbrueckii subsp. } \\
\text { lactis. }\end{array}$ \\
\hline $\mathrm{L}_{11}$ & Curd & + & - & - & + & - & - & + & - & + & - & + & + & - & - & + & - & - & + & - & + & - & - & L. helveticus \\
\hline $\mathrm{L}_{12}$ & Curd & + & - & - & - & + & + & - & + & + & + & + & + & + & + & + & + & + & + & - & + & + & - & L. plantarum \\
\hline $\mathrm{L}_{13}$ & Curd & + & - & - & + & - & - & - & - & - & - & + & + & - & - & - & - & - & - & - & - & - & - & $\begin{array}{l}\text { L. delbrueckii subsp. } \\
\text { bulgaricus }\end{array}$ \\
\hline $\mathrm{L}_{14}$ & Curd & + & - & - & + & - & - & + & + & + & + & + & + & - & - & + & + & - & + & - & + & - & - & L. fermentum. \\
\hline $\mathrm{L}_{15}$ & Curd & + & - & - & - & + & - & - & + & + & + & + & + & + & + & - & - & + & + & + & - & + & - & L. casei subsp. casei \\
\hline
\end{tabular}

RC-Reference culture; + positive; - negative

Table 4. Biochemical Characteristics of bacteria isolated from M17 and Rogosa agar

\begin{tabular}{|c|c|c|c|c|c|c|c|c|c|c|c|c|c|c|c|c|c|c|c|}
\hline $\begin{array}{l}\text { Code } \\
\text { no. }\end{array}$ & Sample & 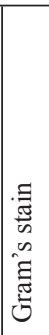 & 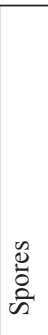 & 豪 & 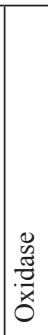 & 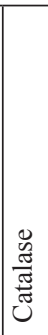 & 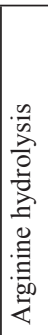 & 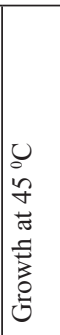 & 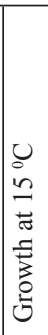 & 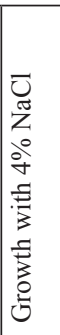 & 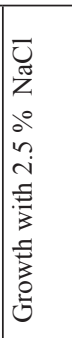 & 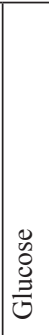 & 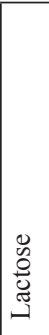 & 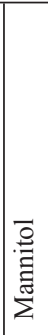 & 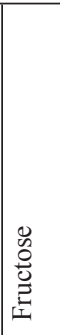 & 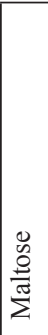 & 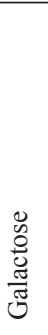 & 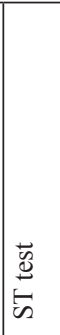 & Streptococcus $s p$. \\
\hline $\mathrm{S}_{1}$ & $\mathrm{RC}$ & + & - & - & - & - & + & + & - & + & + & + & + & - & - & - & - & + & S. thermophilus \\
\hline $\mathrm{S}_{2}$ & Yoghurt & + & - & - & - & - & + & + & - & - & + & + & + & - & - & - & - & + & S. thermophilus \\
\hline $\mathrm{S}_{3}$ & Yoghurt & + & - & - & - & - & - & + & - & - & + & + & + & - & - & - & - & + & S. thermophilus \\
\hline $\mathrm{S}_{4}$ & Yoghurt & + & - & - & - & - & + & + & - & + & + & + & + & - & - & - & - & + & S. thermophilus \\
\hline $\mathrm{S}_{5}$ & Curd & + & - & - & - & - & + & + & - & - & + & + & + & - & - & - & - & + & S. thermophilus \\
\hline $\mathrm{S}_{6}$ & Curd & + & - & - & - & - & + & + & - & - & + & + & + & - & - & - & - & + & S. thermophilus \\
\hline $\mathrm{S}_{7}$ & Curd & + & - & - & - & - & - & + & - & - & + & + & + & - & - & - & - & + & S. thermophilus \\
\hline $\mathrm{S}_{8}$ & Curd & + & - & - & - & - & + & + & - & - & + & + & + & - & - & - & - & + & S. thermophilus \\
\hline $\mathrm{S}_{9}$ & Curd & + & - & - & - & - & - & $+\mathrm{w}$ & - & - & + & + & + & - & $t^{\mathrm{w}}$ & + & + & - & Streptococcus lactis \\
\hline $\mathrm{S}_{10}$ & Curd & + & - & - & - & - & - & $+\mathrm{w}$ & - & - & + & + & + & - & $+\mathrm{w}$ & + & + & - & Streptococcus lactis \\
\hline
\end{tabular}

RC-Reference culture; + positive; $\quad$ - negative; $\quad+{ }^{\text {w }}$ weak positive 
All the isolates with spherical shape gave bands which confirmed that the isolated organisms belong to the genus Streptococcus. The isolates gave bands more or less in the same region as $S$. thermophilus (Figure 2). Since their biochemical characters were also very much similar to that of the reference culture (Table 4), these isolates were conclusively identified as $S$. thermophilus.

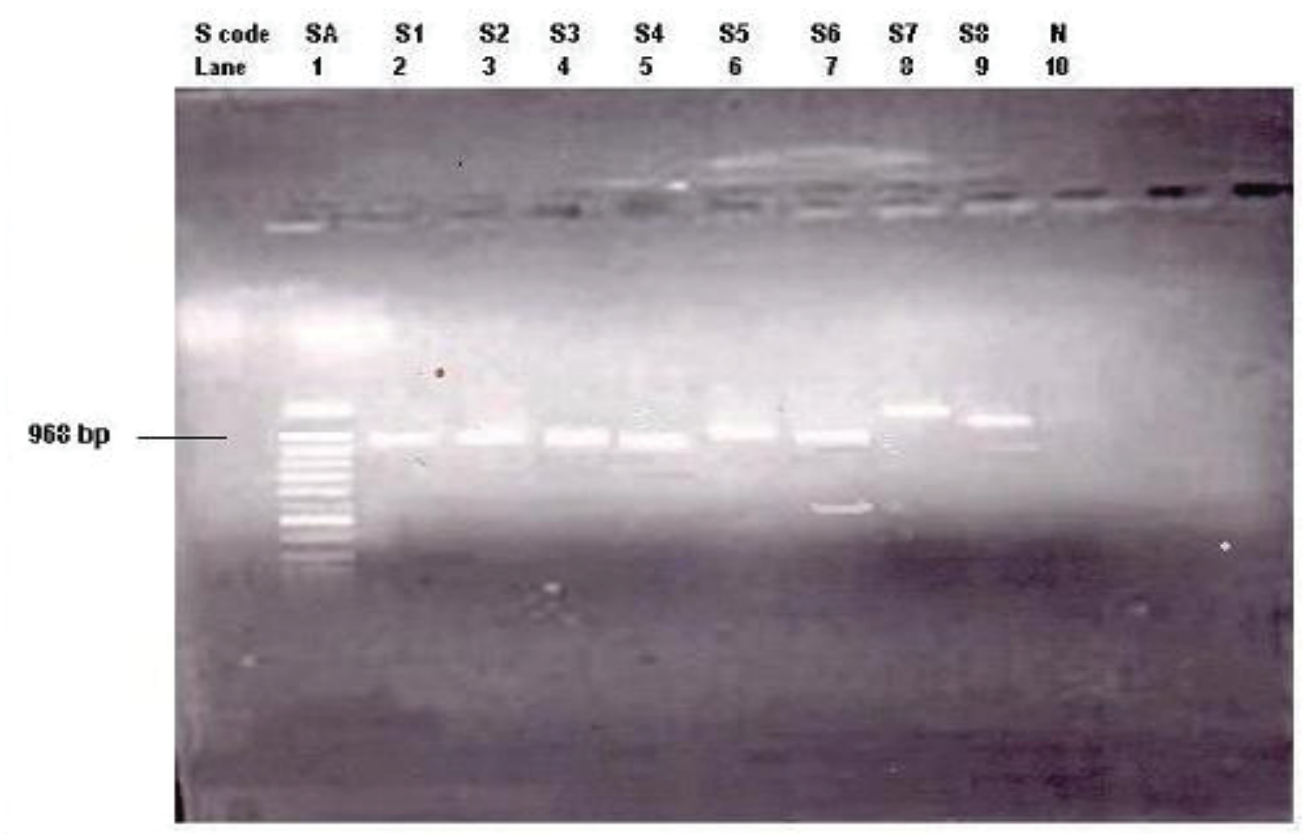

Figure 2. Agarose gel electrophoresis of the PCR amplified DNA for bacterial genomic DNA extracted from bacterial isolates. Lane 1: 100bp ladder (marker), Lane 2: S. thermophilus DMBUK 98050 (positive control) ( $\mathrm{S}_{1}$ ), Lane 3-9 Streptococcus isolates Lane 10: Negative control.

Based on the morphological, biochemical and molecular biological characterization, five different species of Lactobacillus i.e. Lactobacillus delbrueckii subsp. lactis, L. plantarum, L. helveticus, L. fermentum, Lactobacillus delbrueckii subsp. bulgaricus and L. casei subsp. casei and two species of Streptococcus i.e. S. thermophilus and $S$. lactis were identified as constitutes in the microbial consortium. Generally the species identified in this present study were in good agreement with the data reported by Abeyagoonasekera (1981) and Dassanayake et al. (1994). This current study on curd revealed the dominance of lactic acid bacteria after 24 and $48 \mathrm{~h}$ of fermentation, though yeasts present in considerably high numbers. It appeared that, out of the lactic acid bacteria, Lactobacillus was the dominant group in curd when compared with the streptococci species. Since the lactobacillus cells have the ability to decrease the internal $\mathrm{pH}$, they have high acid tolerance level than streptococci species (Siegumfeldt et al., 2000). This feature gives them a competitive advantage over the other lactic acid bacteria. Hence the lactobacilli become the predominant species (Siegumfeldt et al., 2000). The variability of the lactic acid bacteria, yeasts and other heterotrophic bacteria may be attributed to the changing microorganisms at the different fermentation time.

\section{Identification of heterotrophic bacteria and yeasts}

The isolated heterotrophic bacteria were identified as Bacillus species and Micrococcus species after comparing the morphological and biochemical characteristics of these organisms with the data given by Sneath et al., (1986). The isolated Micrococcus species produced slightly yellow coloured colonies, showed growth on casein agar and both catalase and oxidase were positive. Large population of yeast was observed in curd after 48 hours of fermentation. Randomly selected twelve isolates from MYPG medium were identified as Saccharomyces spp. This was based on the some morphological and biochemical characteristics given by Barnett et al., (1985) and six representatives were further compared with commercial strain of Saccharomyces cerevisiae. Out of the six isolates, the carbon assimilation profiles of four isolates indicated that they have similar biochemical profiles as the commercial strain of Saccharomyces cerevisiae. None of the isolates showed $\mathrm{H}_{2} \mathrm{~S}$ production on LA agar (Table 5). Further studies are necessary to identify the yeast isolates to their species level. 
Table 5. Some biochemical properties of yeasts isolated from curd

\begin{tabular}{|c|c|c|c|c|c|c|c|c|}
\hline \multirow{2}{*}{ Test } & \multicolumn{2}{|l|}{ Carbon/ nitrogen } & \multicolumn{6}{|c|}{ Isolated yeasts } \\
\hline & & & $\mathbf{Y}_{1}$ & $\mathbf{Y}_{2}$ & $\mathbf{Y}_{3}$ & $\mathbf{Y}_{4}$ & $\mathbf{Y}_{5}$ & $\mathbf{Y}_{6}$ \\
\hline \multirow{10}{*}{$\begin{array}{l}\text { Assimilation } \\
\text { compounds }\end{array}$} & Glucose & + & + & + & + & + & + & + \\
\hline & Sucrose & + & + & + & + & + & + & + \\
\hline & Lactose & - & - & $+^{w}$ & - & $+^{\mathrm{w}}$ & - & - \\
\hline & Mannitol & - & - & - & - & - & - & - \\
\hline & Fructose & - & - & - & - & - & - & - \\
\hline & Maltose & + & + & + & + & + & - & - \\
\hline & Galactose & + & + & + & + & + & + & + \\
\hline & Raffinose & + & + & + & + & + & + & + \\
\hline & Cellobiose & - & - & - & - & - & - & - \\
\hline & Xylose & - & - & - & - & - & - & - \\
\hline \multirow{4}{*}{$\begin{array}{l}\text { Fermentation of carbon } \\
\text { sources }\end{array}$} & Glucose & + & + & + & + & + & + & + \\
\hline & Sucrose & + & + & + & + & + & + & + \\
\hline & Lactose & + & + & + & + & + & + & + \\
\hline & Mannitol & - & - & - & - & - & - & - \\
\hline \multirow{3}{*}{$\begin{array}{l}\text { Assimilation of nitrogen } \\
\text { sources }\end{array}$} & Peptone & + & + & + & + & + & + & + \\
\hline & Nitrate & - & - & - & - & - & - & - \\
\hline & Ammonium sulfate & + & + & - & - & $+^{\mathrm{w}}$ & - & $+^{\mathrm{w}}$ \\
\hline Urease activity & & + & + & - & $+\mathrm{w}$ & + & - & + \\
\hline
\end{tabular}

$\mathrm{Sc}$ - commercial strain of Saccharomyces cerevisiae

The quantitative analyses of lactic acid bacterial counts as well as yeast counts in $24 \mathrm{~h}$ old curd samples have exceeded the count of $10^{6} \mathrm{CFU} / \mathrm{g}$. The high numbers of yeasts indicates that they constitute a significant part of the microorganisms present in this naturally fermented milk. A distinct feature of this product may be, in addition to the lactic acid fermentation induced by bacteria, a slight or very mild alcoholic fermentation due to yeasts. However curd is regarded as predominantly lactic acid fermentation. Ghassem et al., (2012) have shown that yeast isolated from curd can produce alcohol up to $3.6 \%(\mathrm{v} / \mathrm{v})$. The high numbers of yeasts suggest that they can grow in milk and they may result in enhancement of the flavor of the curd. It is also possible to suggest that they may help the spoilage process of curd. The high levels of yeast population indicate that their metabolism can have certain impact on quality and acceptability on the product. According to Ghassem et al., (2012) the LAB strains were found to be responsible for acidifying the milk whereas the yeast strains caused little changes to the titratable acidity. Another interesting observation made during this study was that growth of some lactic acid bacteria was associated with the growth of yeast cells on MRS agar. The samples with high yeast cell contents also showed high LAB counts and vice versa.

Apart from the LAB, other heterotrophic organisms such as Bacillus and Micrococcus spp. were also isolated from curd. The presence of heterotrophic organisms other than lactic acid bacteria has been considered as contaminants (Dassanayake et al., 1994). During this study, the presence of coliforms and other enterobacteriaceae species such as E. coli and coliforms in curd was not tested, because the microbiological quality of curd is documented in literature (Dassanayake et al., 1994; Weerasekara et al., 2012). But the importance was given to the species of Micrococcus and Bacillus present in curd. The beneficial roles of micrococci in cheese ripening and the production of non-milk aromas by these organisms are documented (Centeno et al., 1996; Taskalidou and Kotzekidou, 2006). Therefore it appears that the presence of these organisms together with LAB in curd may be useful to improve its organoleptic properties. The role played by LAB, yeasts and other heterotrophic bacteria is needed to be further elucidated. The isolated Lactic acid bacteria were not tested for their probiotic potentials. Similar species isolated from curd ex. L. plantarum and L. lactis have been reported as probiotic organisms by other researchers. Shruthy et al., (2011) have reported the probiotic potential among lactic acid bacteria isolated from South Indian curd. Cebeci and Gurakan (2003) reported that L. plantarum has certain properties as probiotic organisms. However it is important to note that probiotic potential of organisms may be strain depended. 


\section{Effect of addition of prebiotics to microbial load in curd}

During the preparation of curd, two commercially available prebiotics [i.e. Hydrolyzed Inulin (HI) and Oligofructose (OF)] were added. Oligofructose (1\%) added curd has resulted (Table 6) in increased counts of yeast and lactic acid bacteria. The counts of yeast have increased from
$10^{6}$ to $10^{8}$ and lactic acid bacteria from $10^{7}$ to $10^{9}$ when compared with the control samples. However there was no difference in counts of lactic acid bacteria, yeasts or heterotrophic bacteria when oligofructose was replaced by the hydrolyzed inulin. Both prebiotics increased the counts of yeast and lactic acid bacteria despite of their differences in the chemical composition (Table 6).

Table 6. Yeast, heterotrophic bacterial and lactic acid bacterial counts in prebiotic added curd samples

\begin{tabular}{|c|c|c|c|c|c|}
\hline \multirow{5}{*}{$\begin{array}{l}\text { Concentration } \\
\text { of the Prebiotic } \\
\text { component }\end{array}$} & \multirow[b]{5}{*}{ Days } & \multicolumn{4}{|c|}{ Microbial counts [CFU $\left(\log _{10}\right) / g$ of product] } \\
\hline & & & \multirow{4}{*}{$\begin{array}{c}\text { Heterotrophic } \\
\text { bacteria }\end{array}$} & & \multirow{4}{*}{$\begin{array}{c}\text { Lactic acid } \\
\text { bacteria } \\
\text { (medium 2) }\end{array}$} \\
\hline & & & & Lactic acid bacteria & \\
\hline & & & & & \\
\hline & & Yeast & & (medium 1)* & \\
\hline \multirow[t]{2}{*}{$1 \% \mathrm{~A}$} & 1 & $8.34 \pm 0.36^{\mathrm{a}}$ & $8.55 \pm 0.09^{\mathrm{a}}$ & $8.89 \pm 0.6^{\mathrm{a}}$ & $7.66 \pm 0.11^{\mathrm{a}}$ \\
\hline & 2 & $8.61 \pm 0.32^{\mathrm{a}}$ & $8.59 \pm 0.21^{\mathrm{a}}$ & $9.19 \pm 0.22^{\mathrm{a}}$ & $7.31 \pm 0.41^{\mathrm{a}}$ \\
\hline \multirow[t]{2}{*}{$1 \% \mathrm{~B}$} & 1 & $8.47 \pm 0.09^{b}$ & $7.87 \pm 0.68^{b}$ & $9.00 \pm 0.23^{b}$ & $8.81 \pm 0.49^{b}$ \\
\hline & 2 & $8.58 \pm 0.13^{\mathrm{b}}$ & $8.66 \pm 0.42^{\mathrm{b}}$ & $9.19 \pm 0.39^{\mathrm{b}}$ & $9.05 \pm 0.56^{\mathrm{b}}$ \\
\hline \multirow[t]{2}{*}{ Control } & 1 & $4.49 \pm 0.62^{\mathrm{a}}$ & $4.93 \pm 0.55^{\mathrm{a}}$ & $3.98 \pm 0.75^{\mathrm{a}}$ & $5.20 \pm 0.82^{\mathrm{a}}$ \\
\hline & 2 & $5.09 \pm 0.61^{\mathrm{a}}$ & $7.50 \pm 1.00^{\mathrm{a}}$ & $4.55 \pm 0.22^{\mathrm{a}}$ & $4.82 \pm 0.52^{\mathrm{a}}$ \\
\hline
\end{tabular}

A - Hydrolyzed inulin

B- Oligofructose (control- without prebiotics)

* medium 1 - L-S differential medium

\# medium 2 - MRS medium

${ }^{\text {a }}$ Each value is the mean $\pm \mathrm{SD}$ of eight observations in four separate experiments

${ }^{b}$ Each value is the mean \pm SD of six observations in three separate experiments

It was also observed, that there was no much difference between the counts obtained for lactic acid bacteria in 24 hrs and $48 \mathrm{hrs}$ fermented prebiotic-added curd samples. Therefore it appears if prebiotics are incorporated to curd, there is a possibility to maximize the growth of lactic acid bacteria within $24 \mathrm{hrs}$. This also indicates that the lactic acid bacteria present in curd may have the ability ferment prebiotics. Kaplan and Hutkins (2000) have identified different strains of $L$. plantarum and $L$. casei as fructooligosaccharide fermenting strains whereas strains of Streptococcus thermophilus have identified as FOS nonfermenting strains. However more research has to be carried out in this area to improve the curd as a value added product i.e. synbiotic product.

The addition of prebiotics reduced the heterotrophic bacteria in curd and this would be remarkable as it gives evidence for the selection of beneficial microorganisms by succeeding the competition. During the fermentation, lactic acid bacteria grow in a neutral $\mathrm{pH}$ medium and convert the medium into acidic conditions by lowering the $\mathrm{pH}$. The low $\mathrm{pH}(5.0-5.2)$ helps to suppress the growth of pathogenic and spoilage bacteria. The heterotrophic bacteria which considered playing a major role in spoilage are suppressed as the lactic acid bacterial growth is enhanced. Therefore, buffalo milk 28 curd may be able to have a long shelf life by incorporating prebiotics, but this aspect needs more investigations especially on the basis of sensory evaluation of the product, in the context of consumer market. It is also important to consider that some heterotrophic bacteria may contribute to the organoleptic quality of the traditional product. This study can be further extended to add commercial value to the traditionally prepared curd i.e. producing symbiotic curd.

\section{Conclusions}

A traditional buffalo milk curd is a result of many activities of a mixed microbial consortium. The present study indicated that the microbial consortium is composed of $L$. delbrueckii subsp. lactis, L. plantarum, L. fermentum and Lactobacillus delbrueckii subsp. bulgaricus, Streptococcus thermophilus and S. lactis. Apart from these organisms, yeasts and heterotrophic bacteria such as Microccocus $s p$. were isolated from buffalo milk curd. The high yeast population indicated that they also play a noteworthy role in the activities of fermentation.

The product developed with the addition of commercially available prebiotic compounds had high lactic acid bacterial 
population and low heterotrophic bacterial counts compared to the traditional product. A further study is therefore needed to be carried out to isolate and identify the LABs, yeasts and heterotrophic bacteria from prebiotic added curd. This will also facilitate selection of organisms and development of a starter culture for the production of synbiotic curd. In this manner the fermentation process can be controlled and it will improve the traditional buffalo milk curd to a value added product based on the nutritional requirements of certain groups of the consumer population.

\section{Acknowledgement}

Authors thankfully acknowledge the technical support provided by Ms. KPR Priyadarshini and Mr. BKA Dias Vijekumara in Department of Microbiology, Faculty of Science, University of Kelaniya for the successful completion of this study.

\section{References}

Abeyagoonasekera Y. H. (1981). Some microbiological studies of the milk curd of Sri Lanka. University of Sri Jayawardenapura. In: http:/hellis.srilankahealthbiblio.org/ handle/ 123456789/8101

Akabanda F., Owusu-Kwarteng J., Glover, R. L. K. and Tano-Debrah K. (2010). Microbiological characteristics of Ghanaian traditional fermented milk product, Nunu. Nature and Science, 8(9): 178-187

Barnett J. A., Payane R.W. and Yarrow D. (1985). Yeasts Characteristic and Identification. Cambridge University Press, UK.

Beukes E. M., Bester B. H. and Mostert J. F. (2001). The microbiology of South African traditional fermented milks. International Journal of Food Microbiology, 63: 189-197.

Cebeci A. and Gurakan C. (2003.) Properties of potential probiotic Lactobacillus plantarum strains. Food Microbiology, 20: 511-518.

Centeno J. A., Varela J. A., Almena M. and Rodriguez-Otero J. L. (1996). Effects of various Micrococcus strains on the ripening and organoleptic characteristics of Arzua cow'smilk cheese. Z. Lebensm Unters Forsch. 203: 546-552.

Dassanayake D. K. M. P., Kodikara C. P., Pathirana K. K. and Widanapathirana S. (1994). Microbiological studies on Rhunu curd. In: Proceedings of Sri Lanka Association for Advancement of Science. 50: 155-156.

Dave R. I. and Shah N. P. (1996). Evaluation of media for selective enumeration of Streptococcus thermophilus, Lactobacillus delbrueckii ssp. Bulgaricus, Lactobacillus acidophilus and bifidobacteria. Journal of Dairy Science, 79: 1529-153.
Dharmasena D. A. N., Kottapola K. G. J. P. and Silva K. F. S. T. (2013). Reuse potential of clay pots for packaging of curd. Digital Library. University of Moratuwa, Sri Lanka. In: http: //di.lib.mrt.ac.lk/handle/123/8965)

Ghassem T., Sadat D. A. and Kulkarni D. K. (2012). Optimization of yeast for ethanol production. International Journal of Research in Ayurveda and Pharmacy, 3(1): 9597.

Guo L., Killefer J., Kenney P. B. and Amick-Morris J. D. (1999). Use of arbitrarily primed polymnerase chain reaction to study Salmonella ecology in a turkey production environment. Poultry Science, 78: 24-31.

Hammes W. P., Weiss N. and Holzapfel W.H. (1992). The genera Lactobacillus and Carnobacterium. In: The Prokaryotes. Barlows, A., Truper, H.G., Dworkin, M., Harder W. and Schleifer K. H. (ed.), Springer, Berlin, 2nd Ed., Vol. 2, pp 1534-1593.

Harrigan W.F. and McCance M. E. (1976). Laboratory methods in food and dairy microbiology. Academic Press , London.

Jayamanne V. S. and Adams M. R. (2004). Survival of probiotic bifidobacteria in buffalo curd and their effect on sensory properties. International Journal of Food Science and Technology, 39: 719-725.

Kandler O. and Weiss N. (1986.) Bergey's Manual of Systematic Bacteriology, Sneath, P. H. A., Mair, N. S., Sharpe, M. E. and Holt, J. G. (ed.), Volume 2, Baltimore, Williams and Wilkins. pp $1209-1234$.

Kaplan H. and Hutkins R.W. (2000), Fermentation of fructooligosaccharides by lactic acid bacteria and bifidobacteria. Applied and Environmental Microbiology. 66(6): 2682-2684

Klein G., Pack, A. Bonaparte C. and Reuter G. (1998). Taxonomy and physiology of probiotic lactic acid bacteria. International Journal of Food Microbiology, 41: 103-125.

Lick S., Drescher K. and Heller K. J. (2001). Survival of Lactobacillus delbrueckii subsp. bulgaricus and Streptococcus thermophilus in the terminal ileum of fistulated Gottingen Minipigs. Applied and Environmental Microbiology. 67(9): 4137-4143.

Lick S., Keller M., Bockelmann W. and Heller K. J. (1996.) Rapid identification of Streptococcus thermophilus by primer specific PCR- amplification. Systematic Applied Microbiology, 19: 74-77. 
Mandal S. K. and Vuppu S. (2013). Preliminary studies on probiotic potential of selected Lactobacillus VIT SSV strains screened from curd samples of Vellore, Bihar, Haryana and Varanasi. International Journal of Pharma and Bio Sciences, 4(2): 193-200.

Medina L. M. and Jordano R. (1994). Survival of constitutive microflora in commercially fermented milk containing bifidobacteria during refrigerated storage. Journal of Food Protection, 56: 731-733.

Nanda D. K., Singh R., Tomar S. K., Dash S. K., Jayakumar S., Arora D. K., Chaudhary R. and Kumar D. (2013). Indian Chilika curd - A potential dairy product for Geographical Indication registration. Indian Journal of Traditional Knowledge. 12(4): 707-713.

Narvhus J. A. and Gadaga T. H. (2003). The role of interaction between yeasts and Lactic acid bacteria in African fermented milks: a review. International Journal of Food Microbiology, 86: 51-60. (DOI:10.1016/S01681605(03)00247-2)

Obodai M. and Dodd C. E. R. (2006). Characterization of dominant microbiota of a Ghanaian fermented milk product, nyarmie, by culture- and nonculture-based methods. Journal of Applied Microbiology, 100: 1355-1363.

Savadogo A., Ouattara C. A. T., Savadogo P. W., Ouattara A. S., Barro N. and Traore A. S. (2004). Microorganisms involved in Fulani traditional fermented milk in Burkina Faso. Pakistan Journal of Nutrition, 3(2): 134-139.

Shah N. P. (2000). Probiotic bacteria: Selective enumeration and survival in dairy foods, Journal of Dairy Science, 83 (4): 894-907.

Sharpe M. E. (1981). The genus Lactobacillus. In: The Prokaryotes, Starr, M.P., Stolp, H.G., Truper, H. G., Barlows, A. and Schlegel, H.G. (ed.), Springer, New York. 1653-1679.

Shruthy V.V., Pavithra M., Gowri S. and Ghosh A. R. (2011). Probiotic potentials among Lactic acid bacteria isolated from curd. International Journal of Research in Ayurveda and Pharmacy, 2(2): 602-609.

Siegumfeldt H., Rechinger K. B. and Jakobsen M. (2000). Dynamic changes of intracellular $\mathrm{pH}$ in individual lactic acid bacterium cells in response to a rapid drop in extracellular pH. Applied and Environmental Microbiology, 66(6): 2330-2335.
Sneath P. H. A., Mair N. S., Sharpe M. E. and Holt J. G. (1986). Bergey's Manual of Systematic Bacteriology, volume 2, Williams \& Wilkins, Baltimore.

Tamime A.Y. and Marshall V.M.E. (1997). Microbiology and Technology of fermented milks. In: Microbiology and Biochemistry of Cheese and Fermented Milk. Law, B.A. (ed.), Blackie Academic and Professional, London. pp 57133.

Taskalidou E. and Kotzekidou P. (2006). Fermentation biotechnology of animal based traditional foods of the Middle East and Mediterranean region. In: Food Biotechnology. Pometto, A., Shetty, K., Paliyath, G. and Levin, R.E. (ed.). CRC Press Taylor and Francis group. pp $1830-1850$.

Weerasekera, W.M.S.I.M., Karunarathne, G.M.C.R. and Prathapasinghe, G.A. (2010). Assessment of quality parameters in curd and yoghurt of small scale processors in North Central Province. Wayamba Journal of Animal Science, 2: 26-29.

Wulijideligen S., Arakawa K., Miyamoto M. and Miyamoto T. (2013). Interaction between lactic acid bacteria and yeasts in airag, an alcoholic fermented milk. Animal Science Journal, 84: 66-74. (DOI:10.1111/j.17400929.2012.01035.x)

Yodoamijoyo R. M., Tirza Z., Herastuti S. R., Tomomatsu A., Matsuyama A. and Hosono A. (1983). Microbiological aspects of Dadih in Indonesia. Journal of Dairy and Food Science, 32: 7-14.

Zourari. A., Accolas. J., and Desmazeaud. M. (1992). Metabolism and biochemical characteristics of yogurt bacteria - A review. Le Lait, 1-34. 